\title{
Metaphors about the Concept of 'Museum' of 4th Graders in One Elementary School in Turkey
}

\author{
Ayşe Mentiş Taş, ${ }^{1, *}$ \& Nihal Yıldız ${ }^{2}$ \\ ${ }^{1}$ Ahmet Keleşoğlu Faculty of Education, Elementary School Teacher Training Department, \\ Necmettin Erbakan University, Konya, Turkey \\ ${ }^{2}$ Faculty of Education, Elementary School Teacher Training \\ Department, Karamanoğlu Mehmedbey University, Karaman, Turkey \\ *Correspondence: Ahmet Keleşoğlu Faculty of Education, Elementary School Teacher \\ Training Department, Necmettin Erbakan University, Karaman, Turkey. E-mail: \\ aysementistas@hotmail.com
}

Received: July 2, 2015 Accepted: November 3, 2015 Published: November 20, 2015

doi:10.5296/ije.v7i4.8599 URL: http://dx.doi.org/10.5296/ije.v7i4.8599

\begin{abstract}
Museums, which have the aim of protecting the cultural heritage, are places used not only to preserve and exhibit the materials from the past, but also to use these materials in accordance with educational purposes. The aim of this study is to determine the views of $4^{\text {th }}$ graders in elementary schools on the concept of 'museum' through metaphors. The study group consisted of 52 fourth graders who were attending an elementary school during the school year of 2014-2015 and who had visited a museum before. In the study, some forms with the statement "Museums are like ....., because ....." were delivered to the students and they were asked to complete the statement by filling in the blanks. In the study, it was attempted to answer these two questions: 1) which metaphors do the $4^{\text {th }}$ graders have about the concept of 'museum'? 2) According to their common features, under which categories those metaphors suggested by the students about the concept 'museum' could be categorized? To analyze the data, the content analysis method was used. In the study, the categories were named as 'traveling to the past,' 'providing information,' 'exhibition,' 'reflection' and 'preservation.'
\end{abstract}

Keywords: museum, metaphor, elementary school 


\section{Introduction}

Museums, having a significant role in preserving the cultural heritage — which establishes a connection between the past, today, and tomorrow-and transmitting it to the next generations, have been gaining more importance and new functions. Museums are non-profit organizations that are related to archaeology, arts, science, or humans, that collect all kinds of products found in humans' lives, preserve and exhibit them, that play a role as a bridge between the past and the future, that allow people to enjoy the educational, informational, and research facilities, that support learning and creativity, and that have the characteristics of universality and sustainability (Mercin, 2002: 44). The Ministry of National Education defined museums as places not only for exhibiting the works gathered from various subject fields all together, such as science, arts, folklore, and antiques, but also for exhibiting the works containing just a single subject, such as the natural history, ethnography, or aviation (MOE,2008:1). It seems impossible for museums not to be affected by the rapid developments emerging in social, economic, environmental, and political aspects. In order to keep up with these developments, it has been gaining importance to keep the sustainability in responding to the needs of the society.

Sustainability, as a concept, is defined as a participatory process that considers being prudent about using the society's social, cultural, scientific, natural, and human resources as important from a social perspective (Gladwin et al. 1995; cited in: Tıraş, 2012: 59). However, sustainability in museums includes reviewing the basic principles of museum works, assessing the cultural needs and facilities of the society, and the extent to which museums address these cultural situations (Onur, 2012:25). In his article about museums and sustainability published in the news of the Network of European Museum Organisations, Maurice Davies suggested that although museums have the purpose of preserving the collections forever, those collections could rarely sustain their existence more than a few years, but the sustainable museums could be sustained for more 20-30 years than this (NEMO, 2010: 5).

The concept 'culture' within the context of sustainable development was addressed as the fourth element of sustainability, as well as economy, society, and environment, in the Johannesburg International Meeting, held in 2002. The attitude and status of a country are determined according to the state of the country in giving importance to preserving the sustainability, as well as the culture and cultural heritage, paying attention to these elements, and sustaining the policies on this subject. It is necessary to use the resources accurately by evaluating the priorities in accordance with the amplitude of the requirements of museums, which has an important role in preserving and sustaining the culture and the collections representing the culture. The subject of establishing the sustainability of museums in terms of the efficient management of resources is addressed under three main topics regarding the environmental, economic and social evaluation. In order to establish the sustainability in the management and operation of museums, it is important to manage, preserve the resources, present them to visitors, consider the marketing strategies and the needs of visitors, and manage the staff and all resources efficiently (Ayözcan Atalar, 2012:1-2). 
In many countries, including our country, museums have sustainability policies. In some countries, museums are autonomous in all aspects; however, in other countries, including Turkey, museums sustain their existence affiliated with the ministry. For example, Australia has regulated the main principles of sustainable museums in a guidebook concerning the policies and practices related to sustainability in museums under the titles of 'education and support,' 'decision making,' 'activities,' 'policies,' and 'practices and functions.' The economic aspects of sustainability, management of sustainable collection, education for sustainability, new buildings for museums, supply, waste management, and management of water, energy, motor vehicle and environmental pollution, and application methods of labour training programs are defined in practical applications for sustainability in museums (www.museumsaustralia.org.au). The Association of Museums emphasized that while designing the sustainability principles for museums, these points should be taken into consideration:

- Preserved and valuable cultural and natural environments are sensitive to their visitors and museum effects.

- In search of reaching the excellence, long-term and deep relations must be established with visitors.

- The heritage created with the help of previous generations is transmitted to the next generations as informative collections.

- Collections must be managed properly.

- Energy and other supplies must be used optimally.

- Opportunities for encouraging and exhibiting sustainable development must be taken into consideration.

- For regional and general liveliness, the economic, social and cultural responsibilities must be shared collaboratively.

- The staff must be trained; museums' proposals must satisfy and reward the staff, and must assess their experiences.

- Long-term goals must reflect the expectations of society from museums.

- Museums must design plans considering the sustainable developments in all of their activities, policies and works.

- Museums must join other museums and organisations in order to provide the optimal way of facing their goals in the long run (www.museumsassociation.org).

Sustainability is related not only to preserving and transmitting the cultural heritage, but also to using this heritage in education field. In our country, with the renewed primary education program in 2005, it was planned that education would not be limited only to school setting but continue outside the school as well. The necessity that various learning environments should be used within this context has emerged. Museums have gained more importance for being places where this learning environment will be established and various learning and teaching strategies found in the program could be used. In many studies conducted, it was concluded that museums have importance in improving various thinking skills of students. 
It should be benefited from museums effectively in both learning and teaching processes. Museums could be used as settings where students are active in both student-centred teaching and learning activities. Mercin (2006: 34) defined the museum training as a part of an individual's education need, and emphasized that it is a process that should be considered as going on for a lifetime, beginning in childhood. The purpose of museum training program should not only be to inform students, but also be to encourage them effectively in improving the skills of questioning, synthesizing, investigating, creativity and imagination (Çakır İlhan, 2009: 343). Historical works from old civilizations and various cultures that students see in museums allow them to gain significant historical thinking skills, such as developing historical empathy, developing evidence-based argument, establishing a relation between the past and the future, understanding the sustainability and the change (Y1lmaz and Şeker, 2011: 22). In a study conducted by Önder et al. (2009: 105-106), considering the educating feature of museums, they suggested the effects of children benefiting from museums as follows:

- Children would learn the ways to improve their knowledge, and compare them with the information from books.

- Children would have the opportunity to see the real versions of the items used in historical eras about which they read in books.

- They would attempt to develop a relation between the historical events and the objects of that era.

- They would compare the differences and similarities between the items in museums and the items of today.

- They would develop the senses of observation, logic, creativity, imagination and appreciation.

- They would improve their aesthetic appreciation.

- They would learn imaginative thinking.

- Museums would show children that development and change are inevitable.

- Children would recognize different cultures.

- They would gain awareness of protecting their cultural values.

- They would learn how to think multidimensionally.

Considering the benefits of using museums in education field, having students visit museums and using museums with educational purposes are becoming more important.

As stated above, the primary education programs in Turkey were redesigned in 2005. Therefore, the programs for Social Studies were also redesigned. In these new programs, the main purpose was to raise individuals who are not just implementing rote learning but who learn how to learn, can think critically and express himself or herself., and have the problem-solving and communication skills. In order to achieve these goals, the need for teachers to use the methods and techniques — other than the expression method — that enable 
students to be active was emphasized. In this regard, it became relatively important to use museums in Social Studies class as an instruction tool because one of the goals of Social Studies class is to transmit the cultural heritage. Museums, places that help the cultural heritage to be transmitted, are constructs that establish a connection between past, present and future. Therefore, it is inevitable that museums are used in the field of education as well. In Turkey, teachers generally prefer the expression method in Social Studies classes more (Özkaral and Taş, 2013). The need to use museums in the field of education started to be expressed more often after the new primary education programs had been prepared and introduced. In this context, it was assumed that it would be significant to arrange a museum tour for the fourth graders included in the study in relation to the achievements within the program, and to determine their perceptions about the tour through metaphors.

\section{Purpose}

The general purpose of this study is to determine the views of elementary school fourth graders who have visited a museum within the scope of Social Sciences class on the concept of 'museum' through metaphors. In accordance with the general purpose, these questions were attempted to be answered:

1- What are the metaphors of fourth graders regarding the concept of 'museum'?

2- Under which categories the metaphors suggested by students regarding the concept of 'museum' could be categorized in terms of their common features?

\section{Method}

\subsection{Study Group}

The study was conducted within the framework of content analysis method, which is considered as one of the qualitative research methods. The study group was composed of 52 fourth-grade primary school students who had attended a museum tour during the first education term of 2014-2015 in Konya, a city located in Central Anatolia Region, located in the central part of Turkey.

\subsection{Collecting the Data}

In the study, students had a planned visit to a museum within the scope of the learning field 'Culture and Heritage' in the unit 'I Am Learning My Past' in the Social Studies class. During the visit, students engaged in various activities, and they played some games in the museum. After the museum visit, forms with the statement 'Museums are like..... because......" were delivered to the students, and they were asked to complete that statement on the form. Data were collected through the forms completed by the students with their own statements. 


\subsection{Analysing and Interpreting the Data}

To analyse the data, the content analysis method was used. Basically, the process implemented in content analysis included gathering the similar data within the framework of certain concepts and themes, and interpreting them by organizing them in a way that readers could understand (Y1ldırım and Şimşek, 2011,227).In analysing the data, first, the forms completed by the students before the data analysis were designated as 'S1'(Student1) and 'S2'(Student2). Then, examining the statements given by the students, the forms of four students who did not provide any justifications were excluded from the analysis. At the second stage, the statements provided by the students were reviewed. 48 valid metaphors were categorized under five different categories. At the third stage, the examples that were thought to optimally express each of those five categories established concerning the 48 metaphors in order to facilitate the validity of the study results were provided in the 'Findings' section. In order to establish the reliability of the study, the categories of two researchers about the metaphors were compared to determine whether the metaphors falling into the five categories were gathered under the respective categories. The comparison revealed a reliability level of .83 (Reliability $=$ agreement $/$ agreement + divergence of views) (Miles and Huberman, 1994).

\section{Findings}

Elementary school fourth graders generated 48 metaphors regarding the concept of 'museum.' These metaphors generated by the students are shown in Table 1.

Table 1. Metaphors of Elementary School Fourth Graders about the Concept of Museum, and Their Percentages

\begin{tabular}{llllll}
\hline Metaphor & f & $\mathbf{\%}$ & Metaphor & f & \% \\
\hline 1-Album & 1 & 2.08 & 14- Rug & 2 & 4.17 \\
2-Shopping Mall & 1 & 2.08 & 15-Book & 3 & 6.25 \\
3-Mirror & 2 & 4.17 & 16-Jewellery Box & 1 & 2.08 \\
4-Information House & 1 & 2.08 & 17-School & 2 & 4.17 \\
5-Bazaar & 1 & 2.08 & 18-Clock & 1 & 2.08 \\
6-Full Notebook & 1 & 2.08 & 19-Art House & 2 & 4.17 \\
7-Photograph & 1 & 2.08 & 20-Magic Curtain & 1 & 2.08 \\
8-Camera & 2 & 4.17 & 21-Magic Cabinet & 2 & 4.17 \\
9-Planet & 1 & 2.08 & 22-Chest & 1 & 2.08 \\
10-Map & 1 & 2.08 & 23-Time Machine & 11 & 22.91 \\
11-Treasure Chest & 2 & 4.17 & 24-Time Tunnel & 5 & 10.42 \\
12-Treasure Room & 2 & 4.17 & & & \\
13-Safe & 1 & 2.08 & & & \\
\hline Total & & 48 & 100 & \\
\hline
\end{tabular}




\section{Macrothink}

In the study, 48 students produced 48 metaphors; however, the number of metaphors produced became 24 after gathering the same metaphors produced.

Table 2. Categories Regarding the Metaphors

\begin{tabular}{lcc}
\hline Category & f & \% \\
\hline Traveling to the past & 20 & 41.66 \\
Providing & 8 & 16.66 \\
Information & 6 & 12.5 \\
Exhibition & 7 & 14.58 \\
Reflection & 7 & 14.58 \\
Preservation & & \\
Total & 48 & 100 \\
\hline
\end{tabular}

The metaphors produced by the students were more often categorized under the category of Journey to the Past. At this point, it could be suggested that the students related the concept of museum more to the past.

Table 3. Traveling to the Past

\begin{tabular}{lll}
\hline Metaphor & $\mathbf{f}$ & $\mathbf{\%}$ \\
\hline Magic Cabinet & 2 & 4.17 \\
Magic Curtain & 1 & 2.08 \\
Planet & 1 & 2.08 \\
Time Machine & 11 & 22.91 \\
Time Tunnel & 5 & 10.42 \\
\hline Total & 20 & 41.66 \\
\hline
\end{tabular}

The most highly produced metaphor by the students under the category of "Journey to the Past' was 'Time Machine.' Examples of metaphors produced by the students are shown below.

'Museums are like a planet, because it seemed to me as if people used to live in another planet when I saw the items in the museum. The items they used were not the same as today's. I understood that they used to live differently than us." (S.10)

"Museums are like a time machine, because time machines bring people to the past. When we go to a museum, we feel like we are in a time machine. We see old items there. We think of the old times." (S.29)

'Museums are like a magic curtain, because you would see a second life when you open the magic curtain. We go back to our ancestors' time. We feel like we are living in their life." (S.38) 
Table 4. Providing Information

\begin{tabular}{lll}
\hline Metaphor & f & $\mathbf{\%}$ \\
\hline School & 2 & 4.17 \\
Book & 3 & 6.25 \\
Full Notebook & 1 & 2.08 \\
Information House & 1 & 2.08 \\
Map & 1 & 2.08 \\
\hline Total & 8 & 16.66 \\
\hline
\end{tabular}

Examples of metaphors produced by the students under the category of "'Giving Information" are shown below.

'Museums are like a full notebook, because they contain too many historical items. Everywhere is full of historical items. There are writings on historical items. We learn about the past life by looking at the historical items." (S.41)

"Museums are like books, because just as we learn something from books, we could learn something from museums as well." (S.47)

"Museums are like maps, because there are many countries, cities, mountains, plains on maps. We learn the names and locations of them by looking at the map. Museums, just like a map, are also sources of information. Items in museums provide us with information about the past." (S.16)

Table 5. Exhibition

\begin{tabular}{llc}
\hline Metaphor & f & \% \\
\hline Art House & 2 & 4.17 \\
Bazaar & 1 & 2.08 \\
Shopping Mall & 1 & 2.08 \\
Rug & 2 & 4.17 \\
\hline Total & 6 & 12.5 \\
\hline
\end{tabular}

Examples of metaphors produced by the students under the category of "'Exhibition'" are shown below.

"Museums are like shopping malls, because when we go to a shopping mall, we see many different items. There are items in shop windows. Just like in shopping malls, items in glass boxes are exhibited in museums." (S.8)

"Museums are like bazaars, because there are many items in bazaars, there are many sellers trying to show their items to people. When we go to a bazaar, we both see many different things and we entertain ourselves. While visiting a museum, we also see many different items and we entertain ourselves." (S.35)

"Museums are like art houses, because paintings and sculptures are exhibited in art houses, and historical items are exhibited in museums." (S.3) 
Table 6. Reflection

\begin{tabular}{lcc}
\hline Metaphor & f & \% \\
\hline Mirror & 2 & 4.17 \\
Album & 1 & 2.08 \\
Camera & 2 & 4.17 \\
Photograph & 1 & 2.08 \\
Clock & 1 & 2.08 \\
\hline Total & 7 & 14.58 \\
\hline
\end{tabular}

Examples of metaphors produced by the students under the category of "Reflection" are shown below.

"Museums are like mirrors, because mirrors show us items and humans, and thanks to museums, we can see our historical works and important historical items." (S.4)

"Museums are like clocks, because the events happening in every single second are in them. Clocks show the time, and museums show the past times, so we go back to the past." (S.23)

"'Museums are like cameras, because museums show the items from the past, and the photographs taken with cameras show the past as well." (S.15)

Table 7. Preservation

\begin{tabular}{lcc}
\hline Metaphor & f & $\mathbf{\%}$ \\
\hline Safe & 1 & 2.08 \\
Treasure Room & 2 & 4.17 \\
Treasure Chest & 2 & 4.17 \\
Jewellery Box & 1 & 2.08 \\
Chest & 1 & 2.08 \\
\hline Total & 7 & 14.58 \\
\hline
\end{tabular}

Examples of metaphors produced by the students under the category of "Preservation" are shown below.

"Museums are like a safe in which valuable items are kept, because just like a safe, valuable items are kept in museums. They get never lost or stolen. We could see them whenever we want to." (S.22)

'Museums are like cabinets in which valuable items are kept, because we keep valuable items in cabinets. We open them and look at the items whenever we want to. Just like cabinets, museums also keep the historical items, and whenever we want, we visit museums and see them." (S.20)

"'Museums are like treasure rooms, because valuable stones and jewellery are kept in treasure rooms in tales, and museums are places in which valuable items and stones are kept." (S.39) 


\section{Discussion, Conclusion, and Implications}

The metaphors produced by the students in this study implemented in order to determine the metaphors produced by fourth-grade primary school students in relation to the concept of museum after the museum tour implemented within the scope of the Social Studies class, were classified under these five categories: Journey to the Past, Giving Information, Exhibition, Reflection, and Preservation.

The metaphors produced by the students were more often categorized under the category of Journey to the Past. At this point, it could be suggested that the students related the concept of museum more to the past. Given the metaphors produced by the students, "Time Machine", was the most often used expression. This might be caused by the fact that the museum visited was a museum where historical artifacts were being exhibited.

Museums search for the materials belonging to the past of human beings, and the environments in which those materials exist, and preserve them. By presenting the materials obtained to the public, museums attempt to improve, entertain, and educate them. Museums are non-profit organisations that are persistent and permanent in community service. The functions of museums include collection, documentation (archiving), preservation (maintenance - repair), exhibition, and education (Denizci and Mirza, 2012). In this study implemented in order to determine the views of elementary school fourth graders who had visited a museum within the scope of Social Sciences class on the concept of 'museum' through metaphors, the metaphors established by the students were classified under five categories. These categories were named as 'traveling to the past,' 'providing information,' 'exhibition,' 'reflection,' and 'preservation.' The categories created based on the metaphors suggested by the students reflect the functions of museums. Based on this finding, it could be concluded that the students who had visited a museum understood the functions of museums.

Considering the metaphors established by the students, the most often used expression was 'time machine.' This could be caused by the feature of the works exhibited in the museum visited, because it was observed that the terms 'museum' and 'metaphor' were used frequently in the related literature. However, the interesting point was that views about the metaphors could change depending on the type of the items exhibited in the museum, and even various metaphors could be generated depending on the architectural structure of museum, and even the order in which the items were exhibited (Chun and Yu, 2008, Litchfield and Gilson, 2013, Fors, 2012, Toit and Dye, 2008, Levin, 2012). Given the categories, the second most frequently generated metaphors were collected in the category of 'providing information.' The students considered the museum as the place for learning. In studies conducted by Çalışkan and Çerkez (2012), Yılmaz and Şeker (2011), students considered museums as settings for learning.

Consequently, it could be suggested that the metaphors generated by the students after the museum visit played an effective role for students to understand the concept of 'museum,' because metaphors are used as a way of learning in education field (Schwartz and Fischer, 2006, Fors, 2012, Toit and Dye, 2008). Having students visit museums helps them develop affective, cognitive, and psychomotor skills. This is an effective way for students to learn. 
However, using metaphors at suitable times could also make positive contributions to the learning process of students.It could be suggested that the students who attended the museum tour understood the functions of museum, and were successful in explaining them through metaphors.

\section{References}

Ayözcan Atalar, B. (2012). Sürdürülebilirlik Bağlamında Müzecilik: Smithsonian Institute Müzeleri, British Museum ve Bakanlı̆̆ımıza Bă̆lı Müzelerin incelenmesi. Ankara: Kültür ve Turizm Bakanlığı Kültür Varlıkları ve Müzeler Genel Müdürlüğü, Uzmanlık Tezi.

Chun, J., \& Yu, F. (2008). Cultural Metaphors in China:A Visual Experience of Hierarchy and Status Symbols. Intercultural Communication Studies, 17(1), 71-78.

Çakır İlhan, A. (2009). Educational Studies in Turkish Museums. Procedia Social Behavioral Sciences, 1 .

Çalışkan, H., \& Çerkez, S. (2012). An Evaluation of Education with Museum Practices in Social Studies Classes Based on Student Views. International Online Journal of Educational Sciences, 4(1), 162-173.

Denizci, A., \& Mirza, H. (2012). Güzel Sanatlar ve Spor Liseleri Müze Eğitimi 12. Milli $\begin{array}{llll}\text { Eğitim } & \text { Bakanlığı } & \text { Yayınlar1. } & \text { Retrieved }\end{array}$ http://www.meb.gov.tr/ders_kitaplari/2012/ortaogretim/devlet/guzelsanatlar_sporlis/muz ikegitimi_12.pdf.ErişimTarihi

Fors, V. (2012). The empty meeting-place - Museum metaphors and their implication for learning. Designs for Learning, 5(1-2), 130-148.

Levin, A, K. (2012). Review article. Medical Museums and Metaphors of the Body Museum \& Society, 10(2), 141-143.

Litchfield, R.C., \& Gilson, L.L. (2013). Curating collections of ideas: Museum as metaphor in the management of creativity. Industrial Marketing Management, 42(1), 106-112. http://dx.doi.org/10.1016/j.indmarman.2012.11.010

Mercin, L. (2002). Anadolu Güzel Sanatlar Liselerinde Müzelerin Sanat (Resim) Ĕ̈itimi Amaçlı Kullanılmasına İlişkin Yönetici ve Öğretmenlerin Görüşlerinin Değerlendirilmesi. Ankara: Yüksek Lisans Tezi.

Mercin, L. (2006). Resim Dersini Müze Kaynaklı Oluşturmacı Öğrenme Yaklaşımı Etkinliklerine Göre Uygulamanın Erişiye, Kalıcılı̆̆a ve Tutuma Etkisi (Diyarbakır İli Örneği). Ankara: Gazi Üniversitesi Doktora Tezi.

Miles, M,B., \& Huberman, A,M. (1994). Qualitative Data Analysis.(2nd.edition). Thousand Oaks,CA:Sage Publications.

MOE. (2008). İlköğretim 1-8. Sınıflar Türkçe, Matematik, Sosyal Bilgiler, Hayat Bilgisi ile 
Fen ve Teknoloji Dersi Öğretim Programlarında Müze İle Eğitim. Ankara: Talim Terbiye Kurulu Başkanlığı..

Museum Association. (2015). Sustainability and Museums: Your Chance to Make a Difference. Retrieved from http://www.museumsassociation.org/download?id=16398

Museums Australia. (2015). Museums and Sustainibility: Guidelines for Policy and Practice in Museums and Galleries. Retrieved 2015 from www.museumsaustralia.org.au/userfiles/file/Policies/sustainability

NEMO. (2010). Museum and Sustainibility: Practice Examples. Newsletter pf the Network of European Museum Organisation. Retrieved 2015 from http://www.ne-mo.org/fileadmin/Dateien/public

Onur, B. (2012). Çă̆daş Müze Eğitim ve Gelişim Müze Psikolojisine Giriş. Ankara: İmge Kitabevi.

Önder, A., Abacı, A., \& Kamaraj, I. (2009). 'Müzelerin Eğitim Amaçlı Kullanımı Projesi'’: İstanbul Arkeoloji Müzesi’ndeki Marmara Örneklemi. Pamukkale Üniversitesi Eğitim Fakültesi Dergisi, 25(1).

Özkaral,T.C., \& Taş, M.A. (2013). Sosyal Bilgiler Öğretmen Adaylarının Sosyal Bilgiler Öğretmenlerinin Derste Kullandıkları Strateji, Yöntem,ve Tekniklere İlişkin Görüşleri.6. Sosyal Bilimler Ĕ̆itimi Kongresi Kongre Bildiri Özetleri Kitapçı̆̆ı.

Schwartz, M.S., \& Fischer, K.W. (2006). Useful metaphors for tackling problems in teaching and learning. On Campus, 11(1), 2-9.

Tıraş, H.H. (2012). Sürdürülebilir Kalkınma ve Çevre: Teorik Bir İnceleme. Kahramanmaraş Sütçü İmam Üniversitesi İktisadi ve İdari Bilimler Fakültesi Dergisi, Sayı:2.

Toit, H., \& Dye, B. (2008). Empathic Dramatic Engagement as a Metaphor for Learning in the $\begin{array}{lllll}\text { Art } & \text { Museum. } & \text { 7isitor } & \text { Studies, }\end{array}$ http://dx.doi.org/10.1080/10645570801938483

Yıldırım, A., \& Şimşek, H. (2011). Sosyal Bilimlerde Nitel Araştırma Yöntemleri. Ankara: Seçkin Yayıncılık.

Yılmaz, K., \& Şeker, M. (2011). İlköğretim Öğrencilerinin Müze Gezilerine ve Müzelerin Sosyal Bilgiler Öğretiminde Kullanılmasına İlişkin Görüşlerinin İncelenmesi. Ístanbul: Aydın Üniversitesi Fen Bilimleri Dergisi, 1(3), 21-39.

\section{Copyright Disclaimer}

Copyright for this article is retained by the author(s), with first publication rights granted to the journal.

This is an open-access article distributed under the terms and conditions of the Creative Commons Attribution license (http://creativecommons.org/licenses/by/3.0/). 